\title{
DESCOPERIRI HISTOPATOLOGICE LA NIVELUL URETREI PROSTATICE, EVALUATE PRINTR-O NOUĂ TEHNICĂ DE PRELUCRARE A PIESELOR REZULTATE DIN PROSTATECTOMIA RADICALĂ
}

\section{Rezumat}

Baze raționale: Prostatectomia radicală este una din cele mai frecvente opțiuni terapeutice pentru tratamentul cancerului prostatic localizat. Evaluarea anatomopatologică, în mod obişnuit, nu se focalizează asupra implicării uretrei prostatice sau ariei periuretrale, iar tehnicile de secțiune utilizate în mod curent nu permit evaluarea amănunțită a acestei regiuni. De aceea, familiarizarea anatomopatologilor cu procesele patologice ale aceste regiuni este limitată.

Obiective: primul nostru obiectiv a fost de a descrie şi evalua o tehnică nouă pentru analizarea pieselor din prostatectomia radicală, tehnică care prezervă verumontanum-ul şi uretra prostatică. În plus a fost efectuată o evaluare și o descriere sistematică a acestei regiuni.

Metode: Au fost evaluate cincizeci de piese de prostatectomie. T,esutul prostatic a fost supus presiunii continue exercitate de cateterul inserat standard, pe parcursul a câteva ore. Piesele au fost procesate și tăiate în șase părți, cu prezervarea uretrei prostatice în porțiunea posterioară mijlocie. Examinarea globală a glandei prostatice a fost efectuată prin examinarea sistematică a pieselor, în special a zonei periuretrale, descoperirile patologice maligne sau benigne fiind înregistrate.

Rezultate: Tehnica descrisă a fost aplicată cu succes pe toate piesele examinate, permițând stadializarea și stabilirea gradului de diferențiere al cancerului prostatic, totodată fiind posibilă examinarea foarte bună a regiunii periuretrale. Această tehnică nouă este simplu de utilizat și poate fi folosită în orice departament de patologie. În $20 \%$ din specimene, regiunea periuretrală a fost infiltrată de adenocarcinom. În plus, a fost înregistrat un număr mare de descoperiri patologice la nivelul uretrei prostatice şi la nivelul verumontanum-ului. Zona prostatei supusă presiunii directe a cateterului a conținut numeroase arii atrofiate, cu glande alungite.

Concluzii: Familiarizarea cu diversele procese patologice ale uretrei prostatice şi verumontanumului este parțială şi incompletă. Utilizând o tehnică de excizie unică, prin care zona periuretrală este conservată, se permite o evaluare mai bună a acestei zone anatomice. Este posibil ca utilizarea acestei tehnici în continuare să evidențieze procesele patologice care ar putea să aibă importanță clinică.

Cuvinte cheie: prostatectomie radicală, tehnică nouă de secționare, uretră prostatică

\section{Introducere}

Adenocarcinomul prostatei este cel mai comun carcinom al vârstnicului. Prostatectomia radicală este o opțiune terapeutică obișnuită pentru cancerul prostatic localizat. Evaluarea specimenelor din prostatectomia radicală constă în stabilirea gradului histologic al tumorii, extensiei, implicării marginii chirurgicale, penetrării în veziculele seminale, sau invaziei perineurale.

Metoda de secționare a pieselor utilizată în prezent nu conservă uretra în întregime, astfel încât există limitări ale acurateței evaluării histopatologice a uretrei prostatice. Acesta este motivul care ne-a condus la descrierea și evaluarea unui sistem nou de secționare a pieselor, într-un mod care permite o evaluare precisă a acestei zone.

Evaluarea anatomopatologică nu se concentrează asupra implicării uretrei prostatice și a zonei periuretrale, iar tehnica de secționare utilizată obișnuit nu permite evaluarea atentă a regiunii; în consecință familiarizarea patologilor cu descoperirile patologice ale acestei regiuni este limitată.

Histologic, majoritatea cazurilor (95\%) de tumori prostatice sunt adenocarcinoame. Dintre ele, 75\% se dezvoltă în zonele periferice ale prostatei, 20\% în zonele tranziționale și mai puțin de 5\% în zona centrală. 
Prostatectomia radicală include prostata în întregime, capsula prostatică şi veziculele seminale. În prezent, în majoritatea operațiilor, există tendința de a prezerva banda vasculo-nervoasă a capsulei prostatice de ambele părți, pentru a minimiza problemele de impotență şi micțiune ulterioare. Menținerea acestor nervi, care se face prin disecția atentă a fibrelor nervoase de lângă capsulă şi de lângă marginile chirurgicale, presupune riscul de a conserva porțiuni ale tumorii maligne la marginile chirurgicale, care are implicații negative din punctul de vedere al aspectului oncologic al intervenției.

Evaluarea patologică $[1,2]$ a piesei operatorii are o importanță mare în evaluarea dimensiunii tumorale, extensiei intraprostatice, penetrării dincolo de capsula prostatică, implicării veziculelor seminale sau gâtului vezical, invaziei perineurale și implicării marginilor chirurgicale. Gradul de diferențiere este de asemenea important și se evaluează prin utilizarea sistemului de gradualizare Gleason, fiind unul din cei mai importanți parametri de prognostic [3].

$\mathrm{Au}$ fost utilizate numeroase sisteme histopatologice pentru examinarea pieselor de prostatectomie radicală $[4,5,6]$. Ele pot fi sumarizate şi împărțite în două atitudini principale, prima fiind „total sampling-prelevarea globală de probe”, prin care întreaga piesă este secționată de la bază la vârf, prin secțiuni perpendiculare către rect $[1,4]$ la $3-5 \mathrm{~mm}$, prin care întrega prostată este examinată. A doua atitudine se concentrează asupra tumorii, dacă este posibilă vizualizarea macroscopică şi prin prelevarea randomizată de probe din prostată. Această atitudine se bazează pe faptul că adenocarcinoamele prostatice obişnuite sunt de obicei multifocale, astfel încât prelevarea de probe multiple poate fi făcută din locuri diferite.

Pentru acestă atitudine sunt disponibile câteva tehnici, dar toate prelevează doar câteva secțiuni randomizate din partea centrală a prostatei [4], cu îndreptarea atenției către extremitățile și marginile prostatei, astfel fiind incluse vârful prostatei, baza și gâtul vezicii.

Cea mai utilizată tehnică în prezent este secționarea prostatei în patru [2], cu efectuarea unei incizii longitudinale și orizontale prin partea centrală - uretra prostatică (Fig. 1). Utilizând acest sistem, uretra prostatică este divizată, astfel încât evaluarea ariei uretrale este compromisă, iar descrierea nu poate fi efectuată cu acuratețe. Pentru a depăși această dificultate, sunt patologi care preferă să verifice fiecare secțiune ca întreg, dar acest sistem necesită utilizarea unor lamele mari și a unui microtom special, dar care nu este disponibil obișnuit în departamentele de patologie, nici în Israel și nici în lume. Acesta este motivul pentru care am decis să testăm un sistem de secționare care prezervă uretra prostatică, permițând diagnosticul și descrierea diferitelor patologii din această zonă anatomică.

Scopul acestui studiu a fost evaluarea noului sistem de secționare al specimenelor patologice. Acest sistem este unic pentru că prezervă zona centrală a prostatei, respectiv uretra prostatică și verumontanum-ul, dar nu necesită un echipament special precum lamele mari sau microtom special, astfel încât poate fi utilizat în toate departamentele de patologie.

Ca obiectiv secundar, au fost examinate și descrise toate structurile histologice ale prostatei și uretrei. Diferitele patologii ale zonei au fost descrise în concordanță cu apariția și frecvența lor. În timpul acestei examinări, am urmărit și prezența adenocarcinomului în partea centrală a prostatei (în jurul uretrei), ca dovadă a dezvoltării carcinomului în această zonă, sau a proliferării extensive locale.

Menționăm că uretra prostatică nu a fost studiată satisfăcător până acum, întrucât porțiuni ale ei erau pierdute în timpul secționării prin folosirea altor sisteme.

\section{Materiale și metode}

Studiul a inclus 50 de piese de prostatectomie radicală obținute în urma intervențiilor chirurgicale pentru adenocarcinom prostatic. Durata medie a unei operații de prostatectomie radicală a fost de aproximativ patru ore, în această perioadă fiind inserată o sondă Foley de 16 Fr sau 18 Fr în vezica urinară, trecând dincolo de uretra prostatică. 
Specimenele au fost transferate rapid din sala de operație la departamentul de patologie. Ele au fost cântărite şi măsurate, iar suprafața exterioară a fost acoperită cu un colorant de India (două culori- dreapta în roşu şi stânga în albastru). Prostata a fost fixată 18 până la 24 ore în formalină tamponată, apoi marginile chirurgicale proximală şi distală au fost fin raclate. Întreaga glandă prostatică a fost secționată seriat, perpendicular pe suprafața rectală, la intervale de 2-3 mm (Fig. 2).

Secțiunile au fost numerotate în serie, începând de la vârf la bază (Fig. 3).

Secțiunile au fost în continuare secționate, anterior şi posterior, prin secțiuni coronale plane până la uretră, iar apoi fiecare porțiune în trei fragmente, dreaptă, stângă şi mijlocie, astfel încât în final, fiecare felie a fost tăiată în şase părți, cu prezervarea uretrei prostatice în partea posterioară mijlocie (Fig. 4). Fiecare fragment a fost marcat ca: anterior stâng, posterior stâng, posterior mijlociu incluzând tot țesutul zonei periuretrale, anterior mijlociu, anterior drept şi posterior drept.

Specimenele au fost procesate şi incluse în parafină. Blocurile au fost apoi tăiate în secțiuni de 5 microni grosime şi colorate cu hematoxilină-eozină.

Prostata a fost examinată microscopic în întregime pentru scorul histologic Gleason, prezența penetrării capsulei, statusul marginilor de rezecție şi invazia veziculelor seminale. A fost efectuată cartarea fiecărei tumori și a marginilor sale.

În timpul acestor operațiuni, am urmărit prezența adenocarcinomului în zona de tranziție a prostatei (în jurul uretrei) și am selectat acele cazuri care nu prezentau tumori la acest nivel. A fost efectuată o examinare minuțioasă a specimenelor, concentrându-ne asupra zonei periuretrale, fiind înregistrate descoperirile patologice maligne sau benigne, precum și cele post cateterizare.

\section{Rezultate}

Descoperirile patologice în porțiunea posterioară mijlocie ale celor 50 de piese de prostatectomie sunt sumarizate în Tabelul I, împărțite în benigne, maligne și post cateterizare, în concordanță cu incidența în seria investigată.

Tabel I. Descoperiri patologice la nivelul uretrei prostatice

\begin{tabular}{lc}
\hline \multicolumn{1}{c}{ Leziuni patologice } & Număr de cazuri \\
\hline Leziuni maligne & 10 \\
Adenocarcinom periuretral & 1 \\
Carcinom cu celule tranziționale & \\
Leziuni benigne & 15 \\
Polipi uretrali & 14 \\
Noduli hiperplazici & 13 \\
Litiază prostatică & 11 \\
Metaplazie scuamoasă & 10 \\
Cuiburi Von Brunn & 10 \\
Inflamație cronică & 8 \\
Mici formațiuni chistice & 3 \\
Noduli mixoizi pseudosarcomatoși & 1 \\
Nevi albaștri & 1 \\
Amiloidoză & \\
\hline
\end{tabular}

\section{Descoperiri maligne}

În 10 specimene $(20 \%)$, a fost identificat adenocarcinom prostatic în verumontanum și zona înconjurătoare.

La un specimen, a fost depistat carcinom de origine urotelială (carcinom cu celule tranziționale de grad scăzut), fără penetrare în structurile tubulare prostatice, sau în stromă. 


\section{Descoperiri benigne}

În 11 specimene, a fost depistată metaplazie scuamoasă în stratul epitelial care acoperă uretra prostatică. De asemenea a fost semnalată metaplazie scuamoasă și în stratul epitelial al utriculei.

O altă descoperire, care este tipică stratului epitelial tranzițional al vezicii urinare, găsită și în uretra prostatică, au fost cuiburile Von Brunn. Aceste grupuri de celule organizate în cuiburi în ariile bazale ale mucoasei (Fig. 5), au fost găsite la 10 specimene, toate fiind localizate în mucoasa verumontanum-ului.

Similar, în unul din specimene a fost diagnosticată uretrita glandulară (Fig. 6), care de asemenea este o descoperire de obicei la nivelul vezicii urinare.

În multe specimene (15), au fost descoperite modificări polipoide în zona verumontanum. Aceste descoperiri au fost tumefieri viloase ale mucoasei prostatice, acoperite de epiteliu columnar, fiind hiperplazice fără aparențe de premalignitate. La patru specimene, aceste modificări au fost identificate aproape de utriculă, iar la trei, structura histologică a fost de papilom inversat.

T,esutul benign hiperplaziat într-o structură glandulară (hiperplazie adenomatoasă), sau cu o componentă predominant stromală (hiperplazie fibromusculară), a fost identificat în regiunea veromontanum, la 14 specimene. La unele a constat din noduli hiperplazici definiți, iar la altele din țesut hiperplaziat difuz diseminat în stromă.

La 8 specimene au fost identificate chiste de diferite dimensiuni la nivelul veromontanum și ca parte a utriculei. Aceste chiste s-au dezvoltat ca şi chiste de retenție sau chiste de incluziune, acoperite de un singur strat de celule epiteliale, fără semne de displazie.

În cazul a 10 specimene, patologia principală a fost însoțită de infiltrat cronic inflamator în țesutul uretrei prostatice.

În cursul intervenției chirurgicale, toate prostatele au fost cateterizate pe o perioadă de 4-6 ore. Am identificat unele modificări histologice, secundare acestei cateterizări prelungite. Mucoasa uretrală a fost comprimată, prezentând glande alungite.

Litiaza prostatică observată deseori în cursul prostatectomiei transuretrale sub formă de mici pietre cu umbre gălbui, a fost identificată la 13 specimene (Fig. 7). Localizarea tipică este în regiunea apropiată de verumontanum, în special în partea posterioară.

În 3 specimene, au fost descoperiți noduli fibromixoizi pseudosarcomatoși, de natură benignă, conținând elemente celulare fusiforme (similare cu nodulii postoperatori cu celule fusiforme, dezvoltați după prostatectomia transuretrală).

În cazul unui specimen, în vecinătatea tumorii prostatice a fost identificată o modificare rară de tip melanocitic, descrisă ca și nev albastru al prostatei, fiind vorba despre melanocite care conțin un pigment negru, localizate în stroma prostatei (Fig. 8), pentru confirmarea diagnosticului fiind utilizată marcarea imunohistochimică S-100.

La un specimen a fost observată amiloidoza ductelor ejaculatorii, a veziculelor seminale și a vaselor deferente. În acest caz, pentru diagnosticul exact a fost utilizată birefringența și colorarea histochimică cu roșu de Congo (Fig. 9).

\section{Discuții}

Pentru examinarea patologică a prostatei, o mare importanță o are determinarea cu acuratețe a gradului tumoral și diferențierii, pentru prognostic și atitudinea terapeutică.

Gradul patologic este determinat de prezența carcinomului în unul sau ambii lobi, de penetrarea tumorii în capsula prostatică (care definește boala avansată local) și penetrarea veziculelor seminale, sau a gâtului vezicii urinare. De semnalat că în $85 \%$ din cazuri, tumora a fost multifocală [7].

O mare importanță o au marginile chirurgicale ale specimenelor; prezența carcinomului în marginile chirurgicale este un semn indirect pentru remanența în patul prostatic, afectând prognosticul prin riscul crescut pentru recurență locală. În unele cazuri, prezența carcinomului în marginea chirurgicală necesită tratament ulterior, precum radioterapia patului prostatic. 
Nivelul de diferențiere (determinat după scorul Gleason), după cum am menționat, are o mare importanță în determinarea prognosticului pacientului. "Scorul Gleason" este în concordanță cu structura glandulară a tumorii prostatice, fiind evaluat de magnitudine joasă, cu un scor de la 1 la 5 . "Suma Gleason" este însumarea scorului Gleason pentru două tipuri predominante din întregul specimen (cu valori de la 2 la 10 ).

Aproximativ 75\% din tumorile prostatice se dezvoltă în zona periferică a prostatei. De când sunt efectuate proceduri de prostatectomie radicală pacienților cu tumori în stadii precoce de dezvoltare, tumorile sunt limitate obișnuit la nivelul zonei periferice.

În ciuda acestui fapt, unul din posibilele semne ale prezenței unei tumori avansate local este diseminarea tumorii în zona tranzițională, în special în ariile din proximitatea uretrei. Această diseminare a tumorii poate explica simptomele obstructive ale unor pacienți, care includ scăderea intensităţii, întreruperea jetului urinar, efort crescut la micționare și evacuare incompletă.

Metoda obișnuită pentru disecție, utilizată pentru obținerea de probe totale, sau culegerea selectivă de probe de la vârful prostatei, gâtul vezicii și suprafeței posterioare, nu se concentrează asupra examinării regiunii uretrale [8].

Așa cum am menționat anterior, atunci când regiunea uretrală este secționată în patru piese, porțiuni ale uretrei se află în marginea tuturor celor patru secțiuni, această poziție făcând dificilă evaluarea histopatologică a regiunii.

În acest studiu am descris o tehnică simplă de secționare, prin care uretra, verumontanum-ul și ductele ejaculatorii sunt prezervate pe o singură lamă. Această tehnică ne permite examinarea minuțioasă și studiul patologiei acestei regiuni. Tehnica este aplicabilă în orice instituție de anatomie patologică și nu necesită măsuri speciale de secționare și prezervare a probelor.

Prezența carcinomului în regiunea uretrală, așa cum am identificat la 10 specimene (20\%) în această serie, poate fi un indicator al originii din regiunea tranzițională de lângă uretră, din care provin $20 \%$ din tumorile prostatei [7]. Lipsa corelației între prezența țesutului tumoral în apropierea uretrei și nivelul de diferențiere scăzut sau stadiul tumoral avansat, susțin această ipoteză.

Întrucât stratul epitelial care înconjoară uretra prostatică și verumontanum-ul este reprezentat de epiteliu tranzițional, ne putem aștepta la același tip de proces degenerativ și transformare neoplazică ca și în vezica urinară. Astfel, în ciuda rarității, carcinomul cu celule tranziționale în uretra prostatică, în ductele prostatice și chiar cu invazie în stroma prostatei, poate fi diagnosticat. În multe cazuri, carcinomul cu celule tranziționale al prostatei se poate dezvolta în paralel cu cel al vezicii. Chiar şi în seria noastră, am identificat un caz de carcinom cu celule tranziționale la un specimen, limitat la stratul mucos. Această descoperire are o mare importanță în privința necesarului de tratament şi de urmărire la nivelul vezicii, sau a recurențelor la nivelul uretrei. Când gradul carcinomului cu celule tranziționale este ridicat, patologul trebuie să îl diferențieze de adenocarcinomul prostatei cu grad scăzut de diferențiere, care este similar histopatologic, dar răspunde la un alt tratament.

În epiteliul care înconjoară uretra prostatică, au fost descoperite mai multe transformări benigne. La câteva specimene au fost diagnosticate proliferări polipoide în uretra prostatică, verumontanum și utriculă. Aceste descoperiri pot fi împărțite în câteva tipuri: polip al uretrei prostatice care se poate dezvolta din verumontanum, dar care poate fi găsit și în partea posterioară a uretrei prostatice. Acesta este o structură hiperplazică-metaplazică, alcătuită din celule columnare înalte provenite din prostată, uneori cu aparență viloasă. La pacienții tineri, polipii mari pot determina hematurie şi/sau disurie. Excizia lor endoscopică duce obişnuit la vindecare, dar recurențele locale sunt frecvente. În rare cazuri au fost identificate insule maligne în polipi, dar în general aceştia nu sunt premaligni [9].

Papilomul inversat, care este de asemenea o proliferare benignă, dimpotrivă, nu creşte în lamina uretrală ci în stromă. Această leziune se poate prezenta clinic prin hematurie sau simptome iritative $[10]$. 
Dezvoltarea nodulilor hiperplazici benigni este tipică pentru zona de tranziție a prostatei, iar nodulii se găsesc lângă uretră; uneori aceştia au arii de infarctizare sau de transformare la nivelul mucoasei, precum metaplazia scuamoasă.

Metaplazia scuamoasă a epiteliului uretrei prostatice a fost identificată în 11 specimene. Aceasta este o transformare metaplazică a epiteliului cu celule tranziţionale tipic uretrei prostatice şi nu are caracter malign. Uneori, aceste modificări cauzează simptome obstructive, care pot fi secundare hiperplaziei benigne de prostată.

Alte modificări tipice epiteliului cu celule tranziționale în vezica urinară sunt cuiburile Von Brunn și cistita glandulară. Cuiburile Von Brunn sunt grupări de celule organizate la nivelul stratului bazal al mucoasei și au fost identificate în mucoasa verumontanum-ului.

Cistita glandulară poate avea o importanță majoră clinică, pentru că este un semn precoce pentru dezvoltarea unui adenocarcinom în vezica urinară [11]. Similar, o arie de uretrită glandulară a fost identificată la un specimen din seria noastră. Nu se cunoaște dacă această descoperire este premalignă sau nu.

Chiste aproape de uretră, care se pot dezvolta în chiste de retenție sau chiste de incluzie, de dimensiuni variabile; semnificația clinică a acestor chiste nu este clară, dar în cazurile cu dimensiuni mari, fiind leziuni cu dizlocuire, pot cauza obstrucția uretrei sau hematospermie [12,13]. În unele cazuri se poate forma litiază în interiorul chistului, dar aceasta nu a fost identificată în seria noastră.

Litiaza prostatică este constituită din mici pietre formate probabil prin sedimentarea, cristalizarea și calcifierea corpilor amilacei, de aceea este posibil să îi observăm având diferite dimensiuni în țesutul glandular al prostatei. La 13 specimene ale seriei noastre, au fost identificate pietre în țesutul adiacent verumontanum-ului.

O altă descoperire rară în prostată este tumora fibromixoidă pseudosarcomatoasă [14]. În studiul nostru am identificat-o la 3 specimene. Diferențierea între această leziune benignă și tumori având caracteristici similare precum sarcomul și carcinomul sarcomatoid, are o mare importanță datorită tratamentelor diferite.

Tot o descoperire rară este nevul albastru al prostatei [15]. Acesta conține celule ovale alungite, diseminate în stromă, marcate imunohistochimic cu S-100 şi melanocite conținând pigment negrubrun. Este necesară diferențierea între această entitate şi pigmentarea prostatei cu lipofuscină, echivalentul mai obişnuitei pigmentări a veziculelor seminale.

Un procent de 2\%-10\% din glandele prostatice cu hiperplazie benignă sau adenocarcinom, au depozite de amiloid la nivelul vaselor sangvine, sau în regiunea subepitelială. Aceste depozite sunt comune în veziculele seminale, frecvența lor crescând cu vârsta, fiind mai obişnuite la pacienții cu amiloidoza rinichilor, mielom multiplu şi la pacienții cu boli cronice. În majoritatea cazurilor, depunerea de amiloid nu este parte a amiloidozei sistemice, de aceea semnificația clinică a acestei descoperiri nu este clară. Diagnosticul se bazează pe birefringență şi colorarea histochimică cu roşu de Congo [16]. Este esențială diferențierea între amiloidoză şi colorarea nespecifică a corpilor amilacei.

Prezența amiloidului în ductele ejaculatorii este rară, doar câteva cazuri fiind documentate în literatură. La specimenele în care a fost identificată amiloidoza ductelor ejaculatorii, au fost găsite depozite de amiloid și în veziculele seminale [17].

\section{Concluzii}

Cunoștințele privind diversele procese patologice care implică uretra prostatică și verumontanumul este parțială și inadecvată. Utilizarea unei tehnici unice de secționare prin care aria periuretrală este conservată, permite evaluarea mai bună a acestei regiuni anatomice. Este posibil ca utilizarea în continuare a acestei tehnici să aducă la lumină procesele patologice care ar putea avea importanță clinică. 


\section{References (Referințe)}

1. Srigley JR, Amin MB, Bostwick DG, Grignon DJ, Hammond ME. Updated protocol for the examination of specimens from patients with carcinomas of the prostate gland: a basis for checklists. Cancer Committee. Arch Pathol Lab Med, 2000;124(7):1034-9.

2. Rosai and Ackerman's surgical pathology; 9th edition; editor- Rosai J, 1367-1369,2893,2959.

3. Gleason DF, Mellinger GT. Prediction of prognosis for prostatic adenocarcinoma by combined histological grading and clinical staging. J Urol, 1974;111(1):58-64.

4. Srigley JR. Key issues in handling and reporting radical prostatectomy specimens. Arch Pathol Lab Med, 2006;130(3):303-17.

5. Bostwick DG, Montironi R. Evaluating radical prostatectomy specimens: therapeutic and prognostic importance. Virchows Arch, 1997;430(1):1-16.

6. Hall GS, Kramer CE, Epstein JI. Evaluation of radical prostatectomy specimens. A comparative analysis of sampling methods. Am J Surg Pathol, 1992;16(4):315-24.

7. Walsh PC, Retik AB, Vaughan ED, Wein AJ (Eds): Campbell's Urology, Ed 8. Philadelphia, WB Saunders Co, 2002, chap. 2, 85-89,110.

8. Sakr WA, Wheeler TM, Blute M, Bodo M, Calle-Rodrigue R, Henson DE, Mostofi FK, Seiffert J, Wojno $\mathrm{K}$, Zincke H. Staging and reporting of prostate cancer--sampling of the radical prostatectomy specimen. Cancer, 1996;78(2):366-8.

9. Kumar A, Das SK, Trivedi S, Dwivedi US, Singh PB. Genito-urinary polyps: summary of the 10-year experiences of a single institute. Int Urol Nephrol, 2008;40(4):901-7.

10. Fine SW, Chan TY, Epstein JI. Inverted papillomas of the prostatic urethra. Am J Surg Pathol, 2006;30(8):9759 .

11. Garcia Rojo D, Prera Vilaseca A, Saez Artacho A, Abad Gairin C, Prats Lopez J, Rosa Bella Cueto M. Transformation of glandular cystitis into bladder transitional carcinoma with adenocarcinoma areas. Arch Esp Urol, 1997;50(2):187-9.

12. Furuya S, Kato H. A clinical entity of cystic dilatation of the utricle associated with hemospermia. J Urol, 2005;174(3):1039-42.

13. Yildirim I, Kibar Y, Sumer F, Bedir S, Deveci S, Peker AF. Intraurethral prostatic cyst: a rare cause of infravesical obstruction. Int Urol Nephrol, 2003;35(3):355-6.

14. Huang WL, Ro JY, Grignon DJ, Swanson D, Ordonez NG, Ayala AG. Postoperative spindle cell nodule of the prostate and bladder. J Urol, 1990;143(4):824-6.

15. Lew S, Richter S, Jelin N, Siegal A. A blue nevus of the prostate: a light microscopic study including an investigation of $S-100$ protein positive cells in the normal and in the diseased gland. Histopathology, 1991;18(5):443-8.

16. Koren R, Livneh A, Shtrasburg S, Goldwasser B, Linke R, Gal R. Organ-limited amyloidosis of the ejaculatory and deferent ducts, and the seminal vesicles. Amyloid and Amyloidosis. R. A. Kyle and M.A. Gertz Parthenon Publishing Group, New York, 1998,524-526.

17. Maroun L, Jakobsen H, Kromann-Andersen B, Horn T. Amyloidosis of the seminal vesicle--a case report and review of the literature. Scand J Urol Nephrol, 2003;37(6):519-21.

\section{Traducere: Bumbuluț Călin}

